\title{
Assessment of the role of copepods and ciliates in the release to solution of particulate DMSP
}

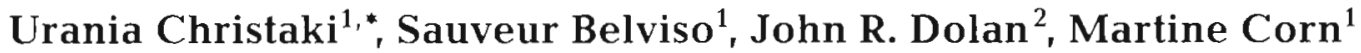

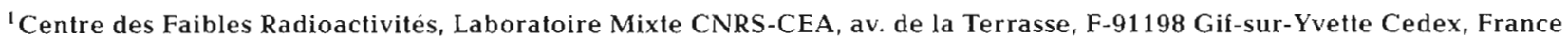 \\ ${ }^{2}$ Station Zoologique, URA 2077, BP 28, F-06230 Villefranche-sur-Mer, France
}

\begin{abstract}
The exchanges between pools of partıculate DMSP (PDMSP) and the total dissolved pool of DMSP and DMS [dDMS(P)], as well as dDMS(P) removal rates were investigated in 4 shipboard incubations of amended and size-fractionated natural planktonic assemblages of the Mediterranean Sea in spring 1995 and in a laboratory experiment with cultured populations. In the shipboard experiments, the effects of different concentrations of copepods and the presence/absence of micrograzers were assessed. Removal rates of dDMS(P), obtained from seawater samples spiked with dDMSP (dissolved DMSP), were linearly correlated with $\mathrm{ADMS}(\mathrm{P})$ levels in the range 10 to $50 \mathrm{nM}$ and were unrelated to size-fractionation treatments. The biological turnover rate constant of $d D M S(P)$ was $0.5 \mathrm{~d}^{-1}$ in most of the experiments, production of dDMS $(P)$ was independent of copepod concentration and lowest in waters from which both copepods and micrograzers $>10 \mu \mathrm{m}$ had been removed. Overall, the results of the shipboard experıments suggested that $(1)$ dDMS(P) production occurred in the microplanktonic food web, probably because pDMSP occurred predominately in the size fraction $<10 \mu \mathrm{m}$ and was unavailable for direct copepod consumption, and (2) dDMS(P) removal rates were likely due to organisms $<10 \mu \mathrm{m}$ in size, probably bacteria. The laboratory experiment involved a common Mediterranean microplanktonic ciliate species (Strombidum sulcatum) grazing on a DMSP-containing Prymnesiophyceae (Isochrysis galbana). The rate of dDMS(P) release from algal DMSP was greatly increased when the phytoplankton was subjected to grazing by ciliates. The majority of prey pDMSP $(>66 \%)$ was released to solution.
\end{abstract}

KEY WORDS: DMSP - Ciliates · Phytoplankton - Grazing · Copepods Mediterranean Sea

\section{INTRODUCTION}

The marine biogeochemical cycle of dimethylsulfide (DMS) involves a complex network of biological and chemical production and utilisation processes which may ultimately influence the flux of DMS to the atmosphere (Groene 1995). DMS is produced from the enzymatic cleavage of dimethylsulfoniumpropionate (DMSP), a compound found in marine particulate matter, notably among certain phytoplankton taxa (Belviso et. al. 1993). Several pathways through which DMS might be formed in seawater have been identified.

A grazer pathway was first addressed in the pioneering work of Dacey \& Wakeham (1986) in which DMS

\footnotetext{
- Present address: Station Zoologique, URA 2077, BP 28, F-06230 Villefranche-sur-Mer, France.

E-mail: christaki@ccrv.obs-vlfr.fr
}

release rates were reported to be several-fold higher when cultured dinoflagellates (Gymnodinium nelsoni and Prorocentrum micans) were grazed by marine copepods (Labidocera aestiva and Centropages hamatus), relative to the ungrazed DMSP-containing phytoplankton. It was concluded that DMS production associated with copepod grazing may be the major mechanism in many marine settings. Some field evidence of the role played by zooplankton in DMS production was provided by Leck et al. (1990). In contrast, it was recently reported (Kwint \& Kramer 1995, Kwint et al. 1996) that copepod grazing on natural phytoplanktonic populations resulted in low DMS production possibly because DMSP was stored in various parts of the body of copepods and was compacted into faecal pellets.

Investigations into the role of the microbial food web in DMS production have also been conducted and yielded conflicting results. For example, Belviso et al. 
(1990) showed that during a long-term (5 d) incubation experiment with size-fractionated plankton populations, the potential for DMS production was confined to the samples containing microplanktonic organisms including micrograzers (ciliates). It was concluded that ciliates grazing on small phytoplankton may be of greater importance than phytoplankton themselves in releasing DMS in the water column. In the more recent study by Wolfe et al. (1994) in which Emiliania huxleyi was offered as a prey to a benthic heterotrophic dinoflagellate (Oxyrrhis marina), it was shown that grazing by herbivorous protists only slightly increased DMS production because not all ingested DMSP was degraded to DMS; some DMSP was stored in the digestive vacuoles and most was metabolised by the grazer

The importance of zooplankton in DMS production is thus questionable as are the respective roles of protists and copepods. Studies thus far have relied on laboratory cultures (e.g. Dacey \& Wakeham 1986) or long-term incubations of populations in mesocosms or microcosms (e.g. Belviso et al. 1990, Kwint \& Kramer 1995). To our knowledge, there have been very few studies of grazer effects on DMSP using natural communities in short-term incubations $(\leq 24 \mathrm{~h})$ and none focusing on plankton from oligotrophic systems. We investigated the role of algae, copepods and protists in releasing dissolved compounds from pDMSP (particulate DMSP) in surface waters of the NW Mediterranean Sea during spring, when levels of pDMSP are particularly high. Results are presented of 4 experiments involving shipboard incubations which were designed to examine the effects of copepod grazing on natural plankton populations. We followed communities containing natural concentrations of copepods, communities to which copepods were added, assemblages without copepods (64 $\mu \mathrm{m}$ screening) and populations without micrograzers $(10 \mu \mathrm{m}$ screening). The results suggested a major effect of micrograzers. In a laboratory experiment, the role of micrograzers was specifically addressed in an attempt to estimate transformation rates. We used a pDMSP algal source, a Prymnesiophyceae (Isochrysis galbana) as prey for a common planktonic ciliate of the Mediterranean Sea, Strombidium sulcatum. While Wolfe et al. (1994) have reported on an in-depth study of a herbivorous protist (Oxyrrhis marina), it is not a species typical of the microzooplankton. Here we report. for the first time, on the efficiency with which a common microzooplankter grazing on a phytoplankter can transform particulate DMSP (referred to as pDMSP in the text) to the dissolved pool of DMSP and DMS (referred to as $\operatorname{dDMS}(\mathrm{P})$ in the text). Note that dissolved DMSP (referred to as dDMSP in the text) constitutes a fraction of the total dissolved pool.

\section{MATERIALS AND METHODS}

Copepods and dDMS(P) production in the Mediterranean Sea. Four shipboard incubations were performed using seawater samples collected at the DYFAMED station $\left(43^{\circ} 25^{\prime} \mathrm{N}, 7^{\circ} 51^{\prime} \mathrm{E}\right)$ during the JGOFS-France cruise 'DYNAPROC' from 1 May to 1 June 1995 on board RV 'Le Suroit'. A size-fractionation approach was used to evaluate the role of the different components of the food web, with a focus on copepods, in the production and consumption of the dissolved compounds dDMSP and DMS. We measured total dissolved DMS(P) pool-referred to as dDMS(P) in the text - without distinguishing between dDMSP and DMS in our analyses.

The incubation experiments were conducted on 11-12 May (Expt A), 14-15 May (Expt B), 27-28 May (Expt C), and 30-31 May (Expt D). Each experiment consisted of incubating seawater subjected to 3 different treatnienis and a controi of untreated seawater. All seawater was collected with Go-Flo bottles from $20 \mathrm{~m}$ depth where the maximum concentration of DMS(P) was found during May 1995 (the control). Water was incubated in 2 l polycarbonate (PC) bottles for $24 \mathrm{~h}$ at $30 \%$ of surface irradiance in a flow-through on-deck incubator flushed with seawater from $3 \mathrm{~m}$ depth. Gas exchange and photochemical decomposition of DMS was likely reduced this way. All materials used were acid-cleaned and rinsed with Milli-Q water. Three bottles were filled with untreated seawater to serve as controls; treatments were as follows.

Treatment 1: copepods added. Centropages typicus were collected from surface waters ( 0 to $50 \mathrm{~m}$ depth) with a $200 \mu \mathrm{m}$ mesh size zooplankton net and starved for several hours before the start of the grazing experiment. Actively swimming females were added to untreated seawater to yield 10 individuals $\mathrm{l}^{-1}$, roughly comparable to $5 \times$ natural concentrations. Duplicate bottles were prepared.

Treatment 2: copepods removed. Seawater was poured gently through a $64 \mu \mathrm{m}$ Nitex mesh to remove adult and immature stages of copepods. The $<64 \mu \mathrm{m}$ size fraction represents micrograzers, Iargely ciliate microzooplankton, and phytoplankton without copepod grazers. Triplicates were prepared.

Treatment 3: micrograzers removed. Seawater was screened through $90 \mathrm{~mm}$ diameter $10 \mu \mathrm{m}$ pore-size Nuclepore PC filters. The method of fractionation was adapted from Verity et al. (1993). The filter was mounted on an acid-washed teflon cylinder that was allowed to sink slowly through seawater contained in a clean 21 PC beaker, thus producing a $<10 \mu \mathrm{m}$ size fraction. The $10 \mu \mathrm{m}$ cutoff was designed to remove micrograzers, primarily ciliate microzooplankton, while allowing nanograzers and most of the phytoplankton to pass. Triplicates were prepared. 
In parallel incubations, the removal rate of $\mathrm{dDMS}(\mathrm{P})$ in each of the 3 different treatments and the control was evaluated in Expts A, B and D. Four 21 bottles, each filled with treated or untreated seawater, were spiked with $\mu$ l quantities of an acidified DMSP aqueous solution freshly prepared from DMSP.HCl (Research Plus, Inc.), to yield final concentrations of dDMSP 2- to 3-fold higher than ambient. Microvolumes $(\mu l)$ of the acid stock solution were added to minimise the effect on the $\mathrm{pH}$ of seawater.

Laboratory experiment with a ciliate micrograzer. Incubations were carried out in six $21 \mathrm{PC}$ bottles (Nalgene) which had been acid washed, Milli-Q water rinsed, and autoclaved. The bottles were filled with DMS(P)-free GF/F filtered seawater (collected at $1000 \mathrm{~m}$ depth, $52 \mathrm{~km}$ off Villefranche-sur-Mer, France) previously kept in the dark with continuous oxygenation with bubbled air.

Strombidium sulcatum, originally isolated from the bay of Villefranche-sur-Mer, was maintained on a bacterised wheat-grain media at $15^{\circ} \mathrm{C}$ as described in Rivier et al. (1985). Ciliates for the experiment were transferred into a bacterised yeast extract medium $\left(0.03 \mathrm{~g} \mathrm{l}^{-1}\right)$ and grown at the experimental temperature of $22^{\circ} \mathrm{C}$ in a temperature controlled incubator. Late log-phase cultures of ciliates (300 to 400 cells $\mathrm{ml}^{-1}$ ) were employed for the experiment. Isochrysis galbana was grown on Guillard's f/2 medium (Guillard 1975) without silicate at $22^{\circ} \mathrm{C}$ in continuous light. Algae used for the experiment came from a log growth culture $\left(10^{5}\right.$ cells $\left.\mathrm{ml}^{-1}\right)$. Final concentrations of ciliates and algae added in experimental bottles were calculated to be around 30 ciliates $\mathrm{ml}^{-1}$ and $1 \times 10^{4}$ algal cells $\mathrm{ml}^{-1}$.

Three solutions were prepared in duplicate: (1) a ciliate control (ciliates alone), (2) a phytoplankton control (phytoplankton alone) and (3) phytoplankton and ciliates together (treatments $\mathrm{C}, \mathrm{P}$ and $\mathrm{PC}$ respectively).

To evaluate the potential of the cultures to remove dDMS(P), 1 bottle of each solution was spiked at the onset of the incubation with dDMSP giving a 10-fold higher initial concentration of dDMSP. These bottles are referred as $\mathrm{Ca}, \mathrm{Pa}$ and $\mathrm{PCa}$.

Each of the 6 bottles was sampled at $0,1,2,3,6,9$, $12,24,36$ and $48 \mathrm{~h}$. The tight sampling (every hour) during the first $3 \mathrm{~h}$ was to check if the dDMSP spike might be very rapidly removed in the spiked bottles (Ca, Pa and PCa).

Phytoplankton cells were enumerated in samples taken at $0,12,24,36$ and $48 \mathrm{~h}$, by epifluorescence microscopy after preservation with sodium tetraborate buffered formalin (4\% final concentration) and staining with DAPI $(4,6$-diamidino-2-phenylindole, final concentration $500 \mu \mathrm{g} \mathrm{l}^{-1}$ ). Ciliates were enumerated at 0,24 and $48 \mathrm{~h}$ on an inverted microscope by Utermöhl's (1958) counting technique. A volume of $10 \mathrm{ml}$ of the samples containing ciliates was fixed with alkaline
Lugol's solution and cleared with $3 \%$ sodium thiosulfate, allowing observation of ingested algae using an inverted microscope equipped with epifluorescence (Zeiss Axiovert, with a $50 \mathrm{~W}$ mercury lamp).

Sulfur analyses. Samples were analysed using a Varian 3300 gas chromatograph equipped with a Pulsed Flame Photometric Detector (PFPD). The PFFD was optimised using repeated injections of a precise amount of gaseous DMS standard and adjusting the hydrogen/air split valve to maximise the DMS peak area. A precision of $1 \%$ was obtained by filling a $1 / 16 "$ $(0.158 \mathrm{~cm})$ outside diameter FEP-Teflon loop, mounted on a Valco Nitronic-60 6-port gas sampling valve, with a calibration mixture made from a permeation tube (Metronics) isothermally operating at $40^{\circ} \mathrm{C}$ in a glass chamber flushed with high-grade helium. The analytical column was a $10 \mathrm{~m} \times 0.32 \mathrm{~mm}$ PoraPLOT $\mathrm{Q}$ from Chrompack operating isothermally at $80^{\circ} \mathrm{C}$. Helium was the gas carrier flowing at a rate of $2 \mathrm{ml} \mathrm{min}^{-1}$.

Water samples were size-fractionated by gravity filtration ( $<\mathrm{GF} / \mathrm{F},<10 \mu \mathrm{m})$ as in Belviso et al. (1993) but only an $8 \mathrm{ml}$ aliquot of the filtrates $(20$ to $50 \mathrm{ml})$ was transferred to glass tubes, treated with cold alkali, sealed with a Teflon faced septa and allowed to sit at room temperature for $12 \mathrm{~h}$ then at $4^{\circ} \mathrm{C}$ before $\mathrm{GC}$ analysis. Only filtration by gravity was applied

The content of a sample tube was drawn into a plastic syringe and immediately injected into the sparging device through a Teflon faced septa. Samples were sparged with helium at $40 \mathrm{ml} \mathrm{min}^{-1}$ for $10 \mathrm{~min}$ and cryotrapped on liquid nitrogen in a $1 / 8$ " $(0.317 \mathrm{~cm})$ diameter FEP-Teflon trap. Nafion dryer tubes were used to remove water after the gas stream had passed through a cold finger at $+1^{\circ} \mathrm{C}$. This kept water from entering the Nafion Dryer and increased its efficiency. The trap was heated at $+95^{\circ} \mathrm{C}$ and its contents transferred for 5 min to the $1 / 16^{\prime \prime}(0.158 \mathrm{~cm})$ FEP-Teflon loop (see above) immersed in liquid nitrogen. Cryofocussing was a necessary step to allow a rapid injection on to the capillary column

DMSP-HCl standards were prepared in acidified Milli-Q water and treated the same way as the seawater samples. The PFPD response was quadratic. Detection limit was about $50 \mathrm{pg}$ DMS, or $0.1 \mathrm{nM}$ in an $8 \mathrm{ml}$ sample. Precision was calculated from size-fractionated samples of the Mediterranean Sea. Four series of triplicates of the whole sample and the size fractions $<10 \mu \mathrm{m},<2 \mu \mathrm{m}$ and $<G F / F$ (total dissolved DMSP) were prepared and analysed for their total DMSP+DMS ( $\Sigma D M S$ ) concentration. The coefficients of variations (SD:mean) of each triplicate were in the range 2.9 to $4.6,1.7$ to $6.7,3.9$ to 8 and 1.5 to $8.9 \%$, respectively, for $\sum$ DMS levels of 10 to $25 \mathrm{nM}$. Precision of pDMSP concentrations calculated by difference between samples was typically 8 to $15 \%$. Because dDMS(P) and pDMSP levels increased rapidly in spring 1995 we duplicated the analyses systematically. 


\section{RESULTS}

\section{Removal of dDMS(P)}

Removal rates were calculated for bottles to which synthetic dDMSP was added (Expts A, B and D, each consisting of a control, a control + copepods, and 2 size fractions $<10 \mu \mathrm{m}$ and $<64 \mu \mathrm{m}$ ). Removal rates were calculated by subtracting dDMS(P) concentration at $t_{24}$ from initial concentrations. Removal rates were not corrected for dDMS(P) production during incubation. Net dDMS(P) removal rates were not markedly different between the treatments and the controls. However, in Expt $B$, the removal rates observed in the size fractions $<64 \mu \mathrm{m}$ and $<10 \mu \mathrm{m}$ were distinctly lower than in the untreated water or copepod added bottles. Based on $t_{0}$ measurements, the bottles containing the size-fractionated material received less dDMSP at the onset of the incubation than the untrcatcd water or bottles to which copepods were added. These results, indicating an apparent relationship between initial concentrations and removal rates in Expt $B$, led us to consider such a relationship in the entire data set

$\mathrm{dDMS}(\mathrm{P})$ removal rates are plotted versus dDMS(P) concentration in Fig. 1. A linear relationship was found (Fig. 1) with $r^{2}=0.77(n=12)$, significant at the $0.1 \%$ level. The slope of the relationship was 0.48 and the intercept $(-0.46 \mathrm{nM})$ was not significantly different from 0 at the $95 \%$ level.

During the laboratory experiment, the net removal of added dDMSP was monitored with a higher resolution than during the field experiments. Levels of $\mathrm{dDMS}(\mathrm{P})$ that were initially about 10 -fold higher in the bottles spiked with dDMSP ( $\mathrm{Pa}$ and PCa) than in the controls

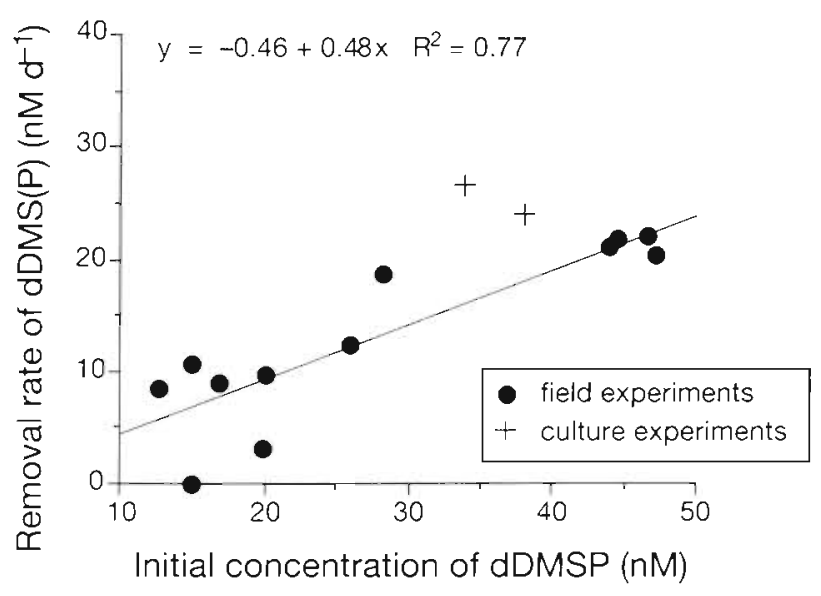

Fig. 1 Ennchment experiments with addition of dDMSP in incubation bottles containing different fractions of the planktonic food web. Removal rates of dDMS(P) versus initial concentrations. Regression considered only the values from the field experiments

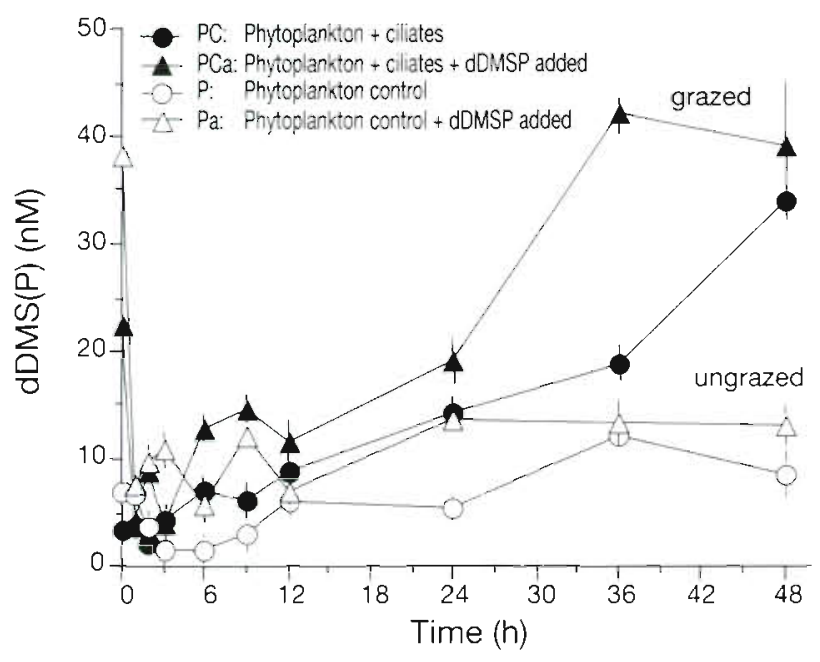

Fig. 2. Temporal variations of $\mathrm{dDMS}(\mathrm{P})$ concentration in bottles $\mathrm{P}$ (phytoplankton), Pa (phytoplankton + DSMPd added), PC (ciliates + phytoplankton) and PCa (ciliates + phytoplankton + DSMPd $\left._{\text {adted }}\right)$. Vertical lines show the range of duplicate measurements

( $\mathrm{P}$ and $\mathrm{PC}$ ) declined to the levels in $\mathrm{P}$ and $\mathrm{PC}$ unspiked solutions after only $1 \mathrm{~h}$ of incubation (Fig. 2). Thus, potential removal rates of $\operatorname{dDMS}(\mathrm{P})$ were high in the cultures of Isochrysis galbana both with and without Strombidium sulcatum. The dDMS(P) concentration in the ciliate-spiked bottle Ca also decreased about 5-fold but took twice as long (Fig. 3). Thus, there was also a large potential for removing $\mathrm{dDMS}(\mathrm{P})$ in the ciliate culture. However, in the Ca bottle the dDMS(P) concentration did not decline to the concentration of the unamended bottle $\mathrm{C}$, but stabilised at a level that was about 7 -fold higher (Fig. 3). Interestingly, in the exper-

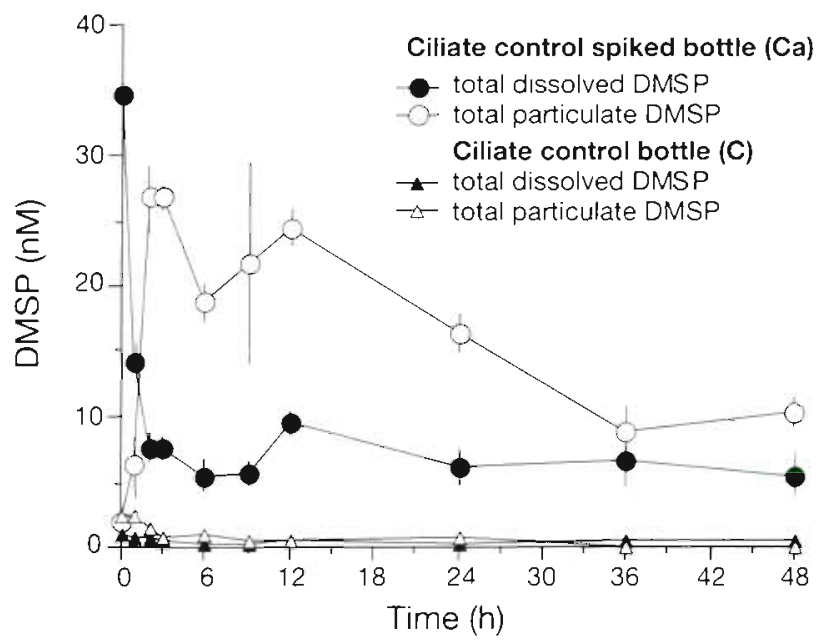

Fig. 3. Temporal variations of dDMS(P) and pDMSP concentrations in bottles $C$ (ciliate control) and $C$ a (ciliate control + $\left.\mathrm{dDMSP}_{\text {added }}\right\}$. Vertical lines show the ranges of duplicate measurements 
imental bottle Ca, containing only ciliates and bacteria spiked with dDMSP, the loss in $\operatorname{dDMS}(\mathrm{P})$ of about $26 \mathrm{nM}$ during the first hours of incubation appeared in the particulate phase (Fig. 3). The total pool of DMS(P) remained rather stable during the first $12 \mathrm{~h}$, then steadily decreased as the pDMSP pool until the end of the experiment.

\section{Copepods and dDMS(P) production in the Mediterranean Sea}

To calculate the production rates of $\operatorname{dDMS}(\mathrm{P})$ in the treatments and the controls we used the changes in dDMS $(P)$ concentrations after a 24 h period of incubation, corrected for $\mathrm{dDMS}(\mathrm{P})$ removal using the relationship we found between the net dDMS(P) removal rates and the dDMS(P) concentrations. The removal rate was roughly equivalent to $50 \% \mathrm{~d}^{-1}$. More precisely, dDMS(P) production was calculated as follows:

$$
\text { Production }=\mathrm{dDMS}(\mathrm{P})_{t_{24}}-0.52 \times \mathrm{dDMS}(\mathrm{P})_{i_{0}}
$$

Overall, there was no consistent trend evident with the concentrations (added, in situ, removed) or simply presence/absence of copepods. The lowest average rates of $\mathrm{dDMS}(\mathrm{P})$ production were found in $<10 \mu \mathrm{m}$ size-fractionated water from which the micrograzers had been removed. However, we encountered a considerable amount of variability among replicates in all the experiments (Fig. 4). For example, in Expt B, the duplicates of the control were so different (14.6 and $0 \mathrm{nM} \mathrm{d} \mathrm{d}^{-1}$ ) that no treatment effects could be shown. In Expts $A, C$ and $D$ the coefficients of variation (SD:mean) of the controls were 36,67 and $67 \%$ respectively.

\section{Ciliate grazing on phytoplankton}

Strombidium sulcatum grazing on Isochrysis galbana was associated with a significant release of dDMS(P) (Fig. 2). The increase of $\mathrm{dDMS}(\mathrm{P})$ in the experimental bottles PC and PCa was pronounced after $12 \mathrm{~h}$ of incubation. The net production of $\mathrm{dDMS}(\mathrm{P})$ in bottles with grazers was 5 to 6 -fold higher than in the bottles containing the phytoplankton alone. The results obtained for pDMSP in bottles with phytoplankton grazers showed an important decrease of the pDMSP in the size fraction $<10 \mu \mathrm{m} 9 \mathrm{~h}$ after the onset of the experiment, while the pDMSP in the phytoplankton controls ( $\mathrm{P}$ and $\mathrm{Pa}$ ) showed a steadily increasing trend (data not shown). These trends paralleled the I. galbana cell numbers (Fig. 5). In the presence of ciliates the dDMS(P):pDMSP ratio steadily increased from about 0.05 at the onset of the experiment to about 0.35 after

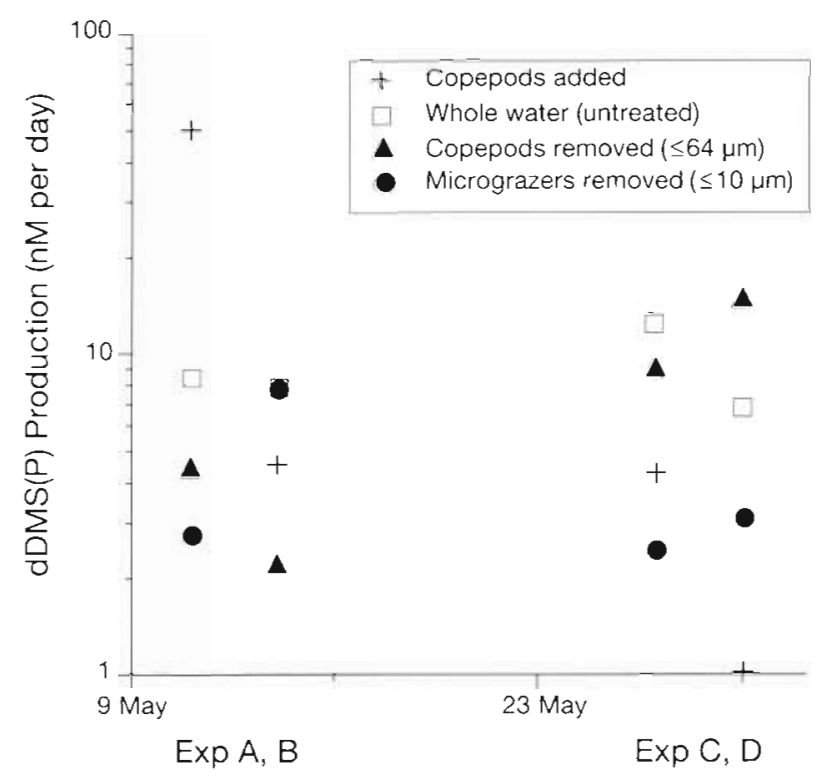

Fig. 4. Production rates of dDMS(P) [corrected for dDMS(P) removal] in different fractions of seawater. Only mean values of triplicates or duplicates are given. Data are plotted on a log scale only to allow separate data points to be distinguished. Pooling all 4 experiments, the overall mean values [nM $\mathrm{dDMS}(\mathrm{P})$ produced $\mathrm{d}^{-1}$ ] for the different treatments were: copepods added $=16.8(\mathrm{SD}=22.77, \mathrm{n}=7)$, whole water $=8.9$ $(\mathrm{SD}=6.82, \mathrm{n}=11)$, copepods removed $=7.8(\mathrm{SD}=5.96, \mathrm{n}=12)$, micrograzers removed $=3.8(\mathrm{SD}=3.45, \mathrm{n}=8)$. Variabllity be . tween replicates precluded demonstration of any treatment effects but based on average values, copepod concentration did not alter dDMS(P) production rates, while removal of micrograzers reduced production

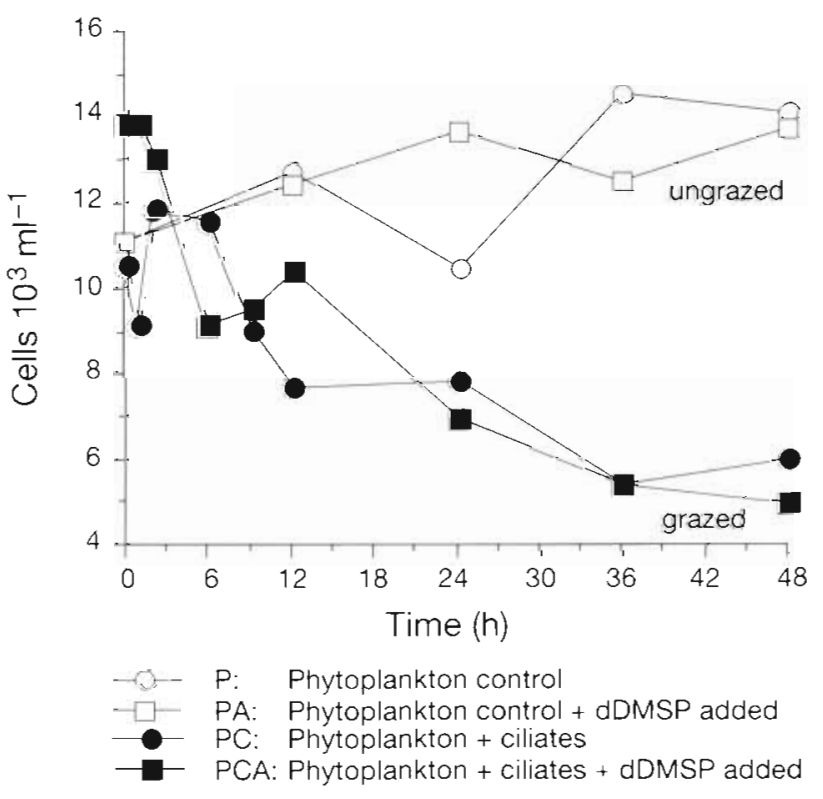

Fig. 5. Isochrysis galbana cell numbers in experimental bottles $\mathrm{P}$ (phytoplankton control). $\mathrm{Pa}$ (phytoplankton control + dDMSP added), PC (ciliates + phytoplankton) and PCa (ciliates + phytoplankton + dDMSP added 


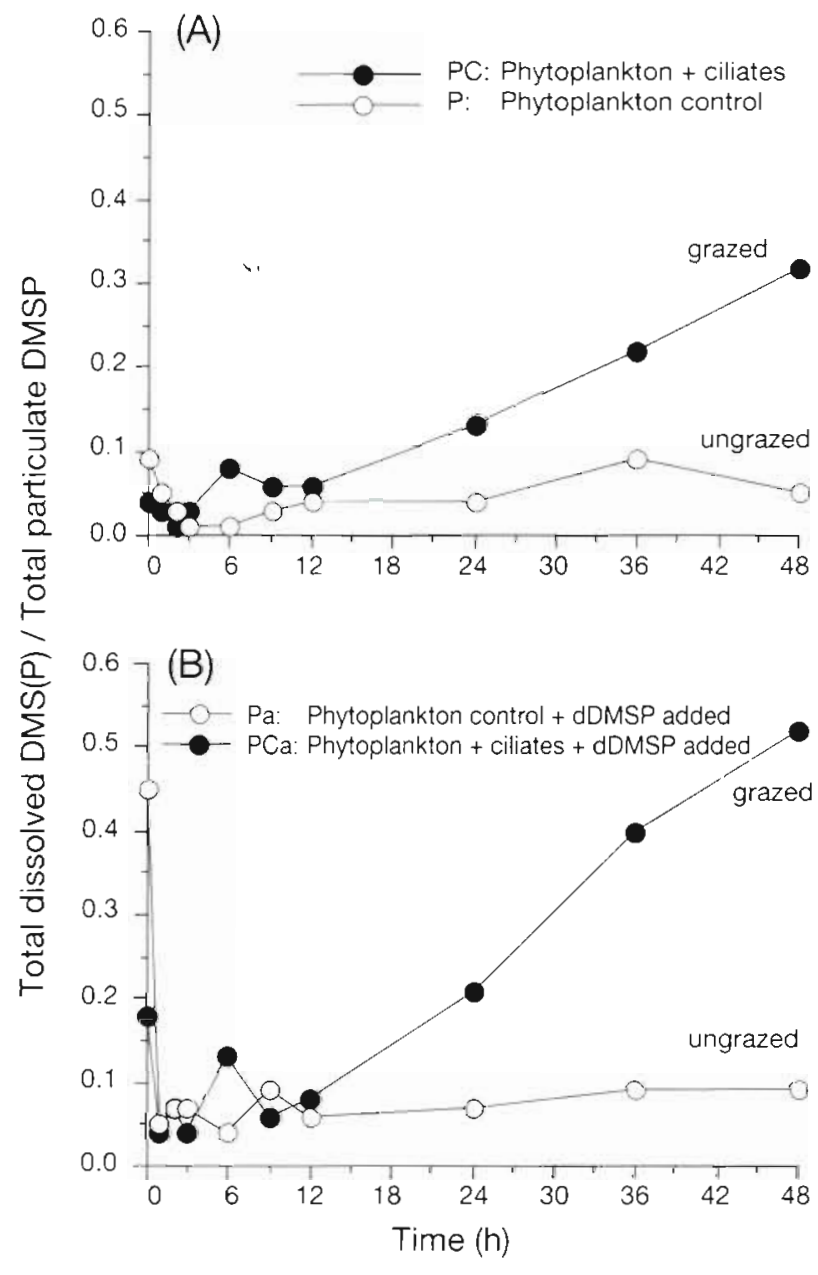

Fig. 6. Strombidium sulcatum grazing on Isochrysis galbana, ratio of dDMS(P):pDMSP. (A) Untreated bottles. (B) Bottles where dDMSP was added

$2 \mathrm{~d}$ (Fig. 6A). In the bottle spiked with dDMSP (PCa), the $\mathrm{dDMS}(\mathrm{P})$ :pDMSP ratio, after the marked decrease of the first hour of incubation-due to removal of added dDMSP - showed the same trend of increase as in the PC bottle (Fig. 6B).

The growth rate $(\mu)$ of Isochrysis galbana was calculated from the cell numbers in the bottles $\mathrm{P}$ and $\mathrm{Pa}$ and was $0.005 \mathrm{~h}^{-1}$. The growth rate of the ciliate was $0.0288 \mathrm{~h}^{-1}$ which equals a generation time (TG) of $24 \mathrm{~h}$. The ciliate grazing rate on phytoplankton $(g=$ $0.010 \mathrm{~h}^{-1}$ ) was calculated from the decrease in phytoplankton cells in bottles PC and PCa corrected for prey and predator growth, following the exponential model proposed by Heinbokel (1978). Thus, the net ingestion rate of $I$. galbana by Strombidium sulcatum was 3 to 4 cells ciliate ${ }^{-1} \mathrm{~h}^{-1}$ (microscopic examination also showed that 3 to 4 ingested cells were visible within $1 \mathrm{~h}$ of adding the prey).

\section{DISCUSSION}

Dissolved DMSP (dDMSP) accounts for a significant fraction of the total DMSP pool (Turner et al. 1988). Field work has shown that the correlation of DMS with dDMSP is stronger than that of DMS with pDMSP (Turner et al. 1988). Because dDMSP is a potential source of DMS, it is reasonable to consider the production of dDMSP and DMS during grazing [total dissolved DMS(P)]. A budget of pDMSP consumption and conversion to dDMSP can be assembled provided that (1) all dDMSP is degraded to DMS and (2) DMS is not rapidly removed from the incubation bottles (naturally or using specific inhibitors). Conditions (1) and (2) were satisfied in the grazing experiments of Wolfe et al. (1994). However, there is compelling evidence that in most marine settings not all dDMSP is degraded by microbes to DMS and the DMS produced is degraded by bacteria (Kiene \& Service 1991). A second approdch is to use effective inhibitors of dDMSP removal, but there are very few available and they may have indirect effects (Kiene \& Gerard 1995). In our experiments in the Mediterranean Sea where dDMSP concentrations were several-fold higher than DMS, we investigated potential removal rates of dDMSP by spiking with synthetic DMSP and by measuring the decrease in the total pool of dissolved compounds, $\mathrm{dDMS}(\mathrm{P})$, without discriminating between dDMSP and DMS. A relationship between $\mathrm{dDMS}(\mathrm{P})$ concentrations and removal rates was established this way and was used to assemble a budget of $\mathrm{dDMS}(\mathrm{P})$ production during zooplankton grazing on phytoplankton.

Combining the size-fractionation method with the spiking method was a novel way to approach the respective role of copepods and ciliates in the release to solution of DMSP. The turnover rates we calculated from dDMS(P) losses are different from classical kinetic parameterisation because they describe the activity of assemblages of diverse marine organisms rather than single species. During the dDMS(P) removal time courses, dDMSP may have been cleaved and/or demethylated and/or stored and DMS consumed and/or photo-oxidised. These processes are not expected to occur on the same time scale. Kiene (1992) showed that the $24 \mathrm{~h}$ time course of dDMSP concentrations in water samples from the southern Sargasso Sea spiked with dDMSP did not follow first-order kinetics but resembled zero-order kinetics. When the concentrations of dDMSP and DMS are summed, the removal of dDMS(P) definitely does not follow first-order kinetics. Moreover, because the central Ligurian Sea, where our study was carried out, is an oligotrophic area representative of the open ocean, we adopted a linear model for the time course of $\mathrm{dDMS}(\mathrm{P})$ removal. However, a rapid 'first-order' consumption of added dDMSP was ob- 
served by Kiene \& Gerard (1995) from samples collected from Mobile Bay, USA, and a beach on the Gulf of Mexico. Hence, dDMSP removal rates may be more rapid in coastal areas than in the open ocean. Rapid removal of added dDMSP was also observed during our grazing experiments (Fig. 2). Finally, using a linear model it may be possible that we underestimated removal rates, but the turnover time of $\mathrm{dDMS}(\mathrm{P})$ we measured was about $2 \mathrm{~d}$. Our estimate is in agreement with the measurements of Ledyard \& Dacey (1996) in another oligotrophic system, the Sargasso Sea, showing dDMSP turnover times to be in the range 0.4 to $2.8 \mathrm{~d}$.

Bacteria are well-known agents of consumption or transformation of dDMSP and DMS (Kiene \& Service 1991). However, not all bacteria are capable of cleaving DMSP (Visscher et al. 1992, Wolfe et al. 1994). Since a specific enumeration of such specialized bacteria was not carried out, we cannot affirm but only suppose that bacteria were responsible for $\mathrm{dDMS}(\mathrm{P})$ degradation. Our supposition is supported by the fact that similar removal rates were found in different seawater size fractions and cultures of planktonic organisms, where bacteria were always the common constituent.

Our experiments at sea showed the $<10 \mu \mathrm{m}$ filtrates to yield the lowest average rates of $\mathrm{dDMS}(\mathrm{P})$ production. In the NW Mediterranean we found that the majority ( 60 to $90 \%$ ) of pDMSP was in the size fraction $<10 \mu \mathrm{m}$. Hence, dDMS(P) production does not appear to be proportional to pDMSP abundance. Corn et al. (1996) showed that in the size range of picophytoplankton only picoeucaryotes are important carriers of DMSP, while prochlorophytes and cyanobacteria are not. Therefore, the production in the size fraction $<10 \mu \mathrm{m}$ could be attributed to grazing of picoeucaryotes by flagellates. Copepods were also shown to be comparatively unimportant, probably because the phytoplankton was composed of these small cells. The variable results with copepods in our experiments might be due to the low ability of adult copepods to feed on particles of size smaller than $10 \mu \mathrm{m}$ combined with their ability to feed on micrograzers (Stoecker \& Capuzzo 1990, Turner \& Granéli 1992, Christaki \& Van Wambeke 1995). In any event, our results suggest that when pDMSP is found largely in small size fractions the role of copepod grazers in pDMSP transformation is probably small or indirect. In future experiments, it may be desirable to have concurrent measures of phytoplankton loss rates.

Most of the DMSP ingested by copepods appears to be compacted into faecal pellets that are rapidly removed from surface waters due to their fairly high settling rates of tens to hundreds of meters $d^{-1}$ (Kwint et al. 1996). However, usually less than $0.1 \%$ of the particulate DMSP standing crop is exported from sur- face waters through sedimentation (Bates et al. 1994, Corn et al. 1994) and neither dDMSP nor pDMSP nor DMS concentrations have been shown to increase at depth but rather tend to decrease with increasing depth. Thus DMSP is probably rapidly consumed within the faecal pellets during sedimentation.

The laboratory experiment showed that algal pDMSP is converted to dDMS(P) during ciliate grazing. In the non-axenic phytoplankton and ciliate cultures (i.e. bacteria were also present) and also in a mixture, we found that a spike of dDMSP was very rapidly removed. Indeed at $\mathrm{dDMS}(\mathrm{P})$ concentrations of 20 to $40 \mathrm{nM}$, typical of levels observed towards the second half of the grazing experiment (Fig, 2), 15 to $30 \mathrm{nM}$ of dDMS(P) was removed within $1 \mathrm{~h}$. The fate of this amount of dDMS(P) is puzzling. Kiene \& Service (1991) demonstrated that about $70 \%$ of dDMSP removed from seawater samples spiked with dDMSP was not converted to DMS. The loss pathway of dDMSP would be through demethylation. In the non-axenic ciliate culture we observed that dDMS(P) was mostly transferred to the particulate phase (Fig. 3). Then pDMSP steadily decreased to a level that was far higher than the pDMSP levels of the control (Fig. 3). The transfer of removed dDMSP in the particulate phase could clearly be observed in the ciliate treatment (ciliates + dDMSP $\left.P_{\text {awa. }}\right)$ where the DMSP was almost zero in the particulate phase before addition of dDMSP. The concentration of pDMSP in treatments with phytoplankton (phytoplankton + ciliates + dDMSP ${ }_{\text {added }}$, phytoplankton + dDMSP $_{\text {added }}$ ) was in the beginning of the experiment of the order of $130 \pm 21 \mathrm{nM}_{i}$ this high concentration partially masked the eventual trace of the removed dDMSP to be found in the particulate phase (also taking in account the precision of the pDMSP measurements, 8 to $15 \%$ ). Studies on the ability of protozoa to absorb dissolved material showed that some small flagellates are able to utilise dissolved and colloidal material (Sherr 1988) but such capabilities are unknown in planktonic ciliates. It has been shown, however, that a bacteria isolated from cyanobacterium Trichodesmium colonies can accumulate dDMSP intracellularly (Diaz et al. 1992). It is thus possible that dDMSP had been taken up by the heterotrophic bacteria and the ciliates that fed on bacteria. dDMSP rapidly taken up by these organisms was degraded relatively slowly. Recently, Wolfe (1996) found that bacteria isolated from rich substrates were able to accumulate dissolved DMSP, however the production of dissolved DMSP during bacterivory by heterotrophic nanoflagellates occurred only occasionally, and predators metabolized most of the dDMSP.

It should be noted that to sustain a concentration of dDMS(P) in the range 20 to $40 \mathrm{nM}$, typical of levels observed towards the second half of the laboratory 
experiment (Fig. 2), a dDMS(P) production rate of 15 to $30 \mathrm{nM} \mathrm{h}^{-1}$ equivalent to its removal rate would be required at steady state. Such a production rate would induce the exhaustion of the algal DMSP within a few hours unless conversion were balanced by a considerable increase of algal growth. Unknown also are the transformations of an ingested DMSP-containing cell within ciliate food vacuoles. This topic deserves further attention. Nevertheless, we can attempt a rough budget of $\mathrm{DMS}(\mathrm{P})$ consumption and conversion by ciliates. We began by considering that the removal rate of $\mathrm{dDMS}(\mathrm{P})$ calculated using the spiking method may not be representative. By increasing the $\mathrm{dDMS}(\mathrm{P})$ background 5- to 10 -fold at the onset of the experiment we may have maximised dDMS(P) removal. To attempt a budget, we calculated dDMS(P) production during the grazing experiments from the dDMS(P) net production corrected for removal using the relationship in Fig. 1. Support for this approach can be found in the fact that the 2 removal rates calculated using dDMS(P) levels at $t_{0}$ and $t_{0}+24 \mathrm{~h}$ in the bottles Pa- (Phytoplankton + dDMSP added) and Ca (ciliates + dDMSP $_{\text {added }}$ ) (Fig. 2) fitted quite well with the in situ data (Fig. 1). Data from PCa (phytoplankton + ciliates + $\mathrm{dDMSP}_{\text {added }}$ ) were not used because the levels of $\mathrm{dDMS}(\mathrm{P})$ at $t_{0}$ and $t_{0}+24 \mathrm{~h}$ were very close due to the increase in $\mathrm{dDMS}(\mathrm{P})$ release during grazing (Fig. 2). Production of $\mathrm{dDMS}(\mathrm{P})$ during the second half of the experiment was calculated using Eq. (1) and was equal to 26 and $29 \mathrm{nM} \mathrm{d}^{-1}$ in PC (phytoplankton + ciliates) and PCa (phytoplankton + ciliates + $\mathrm{dDMSP}_{\text {added }}$ ) respectively. As far as we know, Strombidium sulcatum excretes indigestible contents of food vacuoles. This 'excretion' by ciliates likely represents release of intracellular phytoplankton DMSP into solution during grazing. This production of dDMS(P) was about $1 \mathrm{pmol}$ ciliate ${ }^{-1} \mathrm{~d}^{-1}$ since the density of ciliates was $30 \mathrm{ml}^{-1}$. During the same period, the amount of algal pDMSP (pDMSP in the size fraction $<10 \mu \mathrm{m}$ ) lost from PC and $\mathrm{PCa}$ was 39 and $28 \mathrm{nM}$, respectively. We then conclude that the majority ( 66 to $100 \%$ ) of lost algal DMSP was released to solution. This is in agreement with the budget proposed by Wolfe et al. (1994) for low predator concentrations, based on grazing experiments using a benthic dinoflagellate (Oxyrrhis marina) and Emiliania huxleyi. Can these results be extrapolated to open marine waters? We suggest that this is highly possible because (1) microzooplankton and autotrophic nanoflagellates including the prymnesiophytes are ubiquitous in open waters and (2) excreta of micrograzers are thought to have low sedimentation rates and thus can remain in surface waters (Mostajir et al. 1995, Stoecker et al. 1995) Excreta can undergo desegregation through which $\mathrm{dDMS}(\mathrm{P})$ would be released.

\section{CONCLUSION}

In a series of shipboard experiments copepod concentrations did not markedly affect the production rate of $\mathrm{dDMS}(\mathrm{P})$ while removal of micrograzers, organisms 10 to $64 \mu \mathrm{m}$ in size, appeared to reduce $\mathrm{dDMS}(\mathrm{P})$ production significantly. It is probable that as most of the pDMSP was in the size fraction $<10 \mu \mathrm{m}$, it was unavailable for direct ingestion by copepods. In a laboratory experiment with a micrograzer, a ciliate isolated from the Mediterranean Sea (Strombidium sulcatum), it was estimated that the ciliate can convert pDMSP to dDMS(P) with an efficiency higher than $65 \%$.

Acknowledgements. The authors thank P. Nival and E. Fukai for ald in the shipboard experiments, $V$. Andersen who organised the DYNAPROC campaign, and the captain and crew of RV 'Le Suroit' F. Rassoulzadegan is gratefully acknowledged for providing laboratory facilities at the Station Zoologique. This work was supported by CNRS, CEA, INSU, IFREMER and EEC under contract EV5V-CT93-0326. This is CFR contribution number 1872 .

\section{LITERATURE CITED}

Bates TS, Kiene RP, Wolfe GV, Matrai PA, Chavez FP, Buck KR, Bloquist BW, Cuhel RL (1994) The cycling of sulfur in surface seawater of the northeast Pacific. J Geophys Res 99:7835-7843

Belviso S, Buat-Ménard P, Putaud JP, Nguyen BC, Claustre H, Neveux J (1993) Size distribution of dimethylsulfoniopropionate (DMSP) in areas of the tropical northeastern Atlantic Ocean and Mediterranean Sea. Mar Chem 44: $55-71$

Belviso S, Kim SK, Rassoulzadegan F, Krajka B, Nguyen BC, Mihalopoulos N, Buat-Ménard P (1990) Production of dimethylsulfonium propionate (DMSP) and dimethylsulfide (DMS) by a microbial food web. Limnol Oceanogr 8:1810-1821

Christaki U, Van Wambeke F (1995) Simulated phytoplankton bloom input in top-down manipulated microcosms: comparative effect of zooflagellates, ciliates and copepods. Aquat Microb Ecol 9:137-147

Corn M, Belviso S, Nival P, Vigot A, Buat-Ménard P (1994) Downward flux of particulate dimethylsulfoniopropionate DMSP in areas of the tropical open ocean. Oceanol Acta $17: 233-236$

Corn M, Belviso S, Partensky F, Simon N, Christaki U (1996) Origin and importance of picoplanktonic DMSP. In: Kiene RP, Visscher PT, Keller MD, Kirst GO (eds) Biological and environmental chemistry of DMSP and related sulfonium compounds. Plenum Press, New York, p 191-201

Dacey JWH, Wakeham SG (1986) Oceanic dimethylsulfide: production during zooplankton grazing on phytoplankton. Sclence 233:1314-1316

Diaz MR, Visscher PT, Taylor BF (1992) Metabolism of dimethylsulfoniopropionate and glycine betaine by a marine bacterium. FEMS Microbiol. Lett 96:61-66

Groene T (1995) Biogenic production and consumption of dimethylsulfide (DMS) and dimethylsulfonjopropionate (DMSP) in the marine epipelagic zone: a review. J Mar Syst 6:191-209 
Guillard RRL (1975) Phytoplankton for feeding marine invertebrates. In: Smith WL, Chanley $\mathrm{MH}$ (eds) Cultures of marne invertebrate animals. Plenum Publishing Corporation, New York, p 29-60

Hembokel JF (1978) Studies of the functional role of tintinnids in the southern California Bight I. Grazing and growth rates in laboratory cultures. Mar Biol 47:177-189

Kiene RP (1992) Dynamics of dimethyl sulfide and dimethylsulfoniopropionate in oceanic water samples. Mar Chem $37: 29-52$

Kiene RP, Gerard G (1995) Evaluation of glycıne betaine as an inhibitor of dissolved dimethylsulfoniopropionate degradation in coastal waters. Mar Ecol Prog Ser 128:121-131

Kiene RP, Service SK (1991) Decomposition of dissolved DMSP and DMS in estuarine waters. Dependence on temperature and substrate concentration. Mar Ecol Prog Ser 76:1-11

Kwint RLJ, Irigoien X, Kramer KJM (1996) Copepods and DMSP. In: Kiene RP, Visscher PT, Keller MD, Kirst GO (eds) Biological and environmental chemistry of DMSP and related suifonium compounds. Plenum Press, New York, p 239-252

Kwint RLJ, Kramer KM (1995) Dimethylsulphide production by plankton communities. Mar Ecol Prog Ser 121:227-237

Leck C, Larrson U, Bagander LE, Johansson S, Hajdu S (1990) Dimethyl sulfide in the Baltic Sea: annual variability in relation to biological activity. J Geophys Res 95: 3353-3363

Ledyard KM, Dacey JWH (1996) Microbial cycling of DMSP and DMS in coastal and oligotrophic seawater Limnol Oceanogr 41:33-40

Mostajir B, Dolan JR, Rassoulzadegan F (1995) Seasonal variations of pico- and nano-detrital particles (DAPI Yellow Particles, DYP) in the Ligurian Sea (NW Mediterranean). Aquat Microb Ecol 9:267-277

Rivier A, Brownlee DC, Sheldon RW, Rassoulzadegan F (1985) Growth of microzooplankton: a comparative study

This article was submitted to the editor of bacterivorous zooflagellates and cliates. Mar Microb Food Webs 1:51-60

Sherr EB (1988) Direct use of high molecular weight polysaccharide by heterotrophic flagellates. Nature 335:348-351

Stoecker DK, Capuzzo JM (1990) Predation on protozoa: its importance to zooplankton. J Plankton Res 12:891-908

Stoecker DK, Putt M, Moisan T (1995) Nano-and micruplankton dynamics during the spring Phaeocystis sp. bloom in McMurdo Sound, Antarctica. J Mar Biol Ass UK $75: 815-832$

Turner JT, Granéli E (1992) Zooplankton feeding ecology: grazing during enclosure studies of phytoplankton blooms from the west coast of Sweden. J Exp Mar Biol Ecol 157: $19-31$

Turner SM, Malin G, Liss PS, Harbour DS, Holligan P.VI (1988) The seasonal variation of dimethylsulfide and dimethylsulfoniopropionate concentrations in nearshore waters. Limnol Oceanogr 33:364-375

Utermöhl H (1958) Zur Vervollkommnung der quantitativen Phytoplankton-Methodik. Mitt Int Verein Theor Angew Limnol 9:323-339

Verity PG, Stoecker DK, Sieracki ME, Nelson JR (1993) Grazing, growth and mortality of microzooplankton during the 1989 North Atlantic spring bloom at $47^{\circ} \mathrm{N}, 18^{\circ} \mathrm{W}$. Deep Sea Res 40:1793-1814

Visscher PT, Diaz MR, Taylor BF (1992) Enumeration of bacteria which cleave or demethylate dimethylsulfoniopropionate in the Caribbean Sea. Mar Ecol Prog Ser 89:293-296

Wolfe GV (1996) Uptake and retention of dissolved DMSP by marne bacteria with subsequent degradation during bactivory. In: Kiene RP, Visscher PT, Keller MD, Kirst GO (eds) Biological and environmental chemistry of DMSP and related sulfonium compounds. Plenum Press, New York, p 277-291

Wolfe GV, Sherr EB, Sher BF (1994) Release and consumption of DMSP from Emilianıa huxleyi during grazing by Oxyrrhis marina. Mar Ecol Prog Ser 111:111-119

Manuscript first received: April 19, 1996

Revised version accepted: July 4, 1996 